\title{
脳波を利用した乳幼児のVisual attentionのとらえ方
}

\section{川崎医大 神経眼科 山崎康子}

緒言

視能矯正を行なつていても実際に有効に刺激 が脳に伝達されているかどうが,また訓練ので きない乳幼児が何に興味を示しているかどうか わからない場合がしばしばある。そこで私共は 注意して物をひろつて見ていく時に眼の動きに 際して後頭部から出現するといわれているラム 夕波を利用して，乳幼児の視精神反射の興味の 対象について他覚的に調べこことができたので 報告する。

\section{実験方法}

症例は視能訓練にがからない者//例,訓練可 能な者25例である。

测定方法は，前回報告しだ） EEGテレメータ 一送受信装置である。これは行動が自由で脳波 の送信と受信が可能でありモニターブラウン管 により観察もでき, 必要部分の記録ができる器

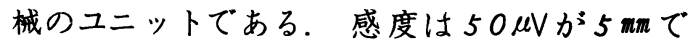
Paper Speed $25 \mathrm{~mm} / \mathrm{sec}$ を使用した。脳波誘導位 置はラムダ波反応がよく出現する後頭結節上 3 $c m$ 上の中央に活性電極をおき耳染を不関電極と する/チャンネル単極誘導を行なつた，测定順 序は,まず閉眼 EEG, 次に開眼で白壁を見てい る時の EEG を测定し， $\alpha$-blocking の出現の有無 を調ぺた. 訓練可能な者に対しては Synoptophore による種々の training 負荷時のEEG変化, Red writing, Reading 施行時の記録を行なつた。訓練 にかかららい乳幼児に対しては，種々のおもち や, 絵本, ブラウン管にうつる自分の脳波など を見せ，その時の脳波変化をモニターブラウン 管で観察し, 必要部分の記録を行ない/O秒間 のラムダ波の出現頻度を求めた.

\section{実験結果}

1. 訓練にかからない乳幼児の反応：3才内 斜視例, 開眼により $\alpha$-blocking が認められた. 白 壁を見ている時は入波の出現頻度は2回/10sec,
おもちやを見た時の入波の出現頻度は, キュー ピーで 2 回/ $10 \mathrm{sec}$, 消防車 8 回/ $10 \mathrm{sec}$, 音か; 出て動〈猿 7 回 $/ 10 \mathrm{sec}$, 動〉犬 8 回 $/ 10 \mathrm{sec}$, ガラガラ5回/10 sec,であつた.

訓練にかかららい乳幼児においては、脳波全 体に5〜8 Hzの振幅の大きい波, 時に3 Hz 以 下の $\delta$ 波が多く見られた。入波の出現は個人差 はあつたが全例に出現していた。目標のない白 壁を見ている時と対象物を見ている時とでは明 らかに入波の出現頻度に差が認められた。おも ちやの中でも自分が興味を示してさわりにいつ た物と，ただじつと見ているだけの物とでは入 波の出現頻度に多少の差が見られた。全体に音 が出て動く猿, 犬, ガラガラなどに入波の出現 が多く見られた。

2. 訓練可能な幼児：8才斜視弱視, 外斜視 例一開眼により $\alpha$ 波の消失と $\beta$ 波, 時に $2 \mathrm{~Hz}$ の不規則徐波が出現し, この徐波に低振幅の速 波が重なつて見られた。入波の出現頻度は白壁 を見ている時／回／10 sec，視力測定時5回／ 10 sec, Red writing 8 回/10 sec, Reading 9 回/


が羿められた。

7 才屈折性弱視一閉眼により9〜10 Hzの $\alpha$ 波が出現し，開眼しても振幅は小さくなるが依 然 $\alpha$ 波が㤎められた。入波の出現頻度は白壁を 見ている時/回/10 sec, 猿/回 $/ 10 \mathrm{sec}$, キ ューピー2回 $/ 10 \mathrm{sec}$, ブラウン管にうつる自 分の脳波を見ている時 4 回 $/ 10 \mathrm{sec}$, 視力測定 時 / 回 / $10 \mathrm{sec}$, Red writing / 回 / $10 \mathrm{sec}$,であつ た. 全体に入波の出現が少なく $\alpha$ 波の出現が目 立つた。

弱視を伴う斜視患者において 8 例中 7 例に $\alpha$ -blocking が認められた.入波は対象物を見ている 時は全例に出現した. 白壁を見ている時と訓練中とで は $\alpha$-blocking の認められなかつた/例を除いては 明らかに入波の出現頻度に差が涊められた。

7 才外斜視例 一 閉眼により9〜10 Hzの $\alpha$ 
波が出現し，開眼により $\alpha$ 波の消失が認められ た。入波の出現は白壁を見ている時は 0 回 $/ 10$ sec, Synoptophore 使用での SPP slide 5 回 $/ 10$ sec, SMP slide 2 回 $/ 10 \mathrm{sec}$ で時々 $\alpha$ 波出現,

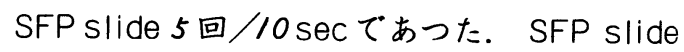
での点滅を行うと入波は3回 $/ 10 \mathrm{sec}$, Kinetic Bi-retinal stimulation を行うと 7 回 $/ 10 \mathrm{sec}$ 出現し 両者の訓練において入波の出現頻度に差が認め られた。

斜視例において/7例中/6例に開眼により $\alpha$ -blocking が認められた。入波の出現頻度は個人 差はあるが、目標のない白壁を見ている時より 对象物を見た時に增加した。訓練方法によつて も入波の出現に差が認められた。開眼時に $\alpha$ 波 が出現しているものは全体に入波の出現が少な かつた。

\section{考按並びにまとめ}

テレメーター法で訓練中の脳波を測定した。 この方法を用いると他覚的にデータが得られ送 信機のとクつけが籣単なため乳幼児にさ之容易 に検査可能であつた。

訓練にかかららな乳幼児において Visual Attention の対象が音が出て動く物であることが他覚的に 入波でキャッチできた。また訓練可能な幼児に おいても個人差, 訓練方法の違いにより入波の 出現頻度に差はあつたが全例入波の出現を認め た。

ラム多波は2)1949年 Evans によつて最初に 報告されて以来多〈の研究がある。従来開眼 3 (4)5) して物をひろつて見ていく時の眼の動きに際し て後頭部から出現し, 閉眼時, 薄暗い場所, 注 意をひくような对象物の乏しい場所では出にく いといわれている。.Scott 6) 等によると動物に おいても出現しVisual activity response であると報 告している。すおわち猿はバナナ，犬は知らな い人，ネコは鏡に写つた自分の顔を見た時など に入波が出現し、ウサギなどの下等動物におい ては出現しないと報告している．

入波の出現は目標のない白壁を見ている時よ り対象物, 特に複雑な罒形, 動く物を見た時に 增加した。 $\alpha$-blocking を羿めなかつた症例にお いては入波の出現が少なく、実際に訓練を行つ
ていても落ち着きがなく注意力も散漫で極めて 扱いにくく治療成績の悪い例であつた。検査や 訓練を行う場合，その子供が興味を持つている 物, 寸なわち Visual attention のかかるものを使 用し、また訓練も興味を示寸方法で行うことが 必要である。その意味で入波の出現頻度が視能 矯正反応の/つの評価法として応用できる可能 性を持つている. しかし入波が出現しているか らといつて, 即訓練効果が上つているかどうか まで結びっけることはできない.

視能矯正におけるこれからの途は自覚法だけ でなく他覚的にデータを得る方向にむかねばな らない。脳波利用の方法がその系口になればよ いと考える。

稿を終るにあたり御指導,御校閲をいただき ました筒井純教授に深謝いたします。

文献

1. 前田康子, 深井小久子, 筒井純： EEG 广 レメーターの視能矯正における応用, 眼科, 18: 307, 1976.

2. C.C.Evans: Spontaneous excitation of the visual cortex and association areas-Lambda Waves, Electroenceph. Clin. Neurophysiol., 5: 69, 1953.

3. 大熊煇雄：臨床脳波, 金原出版, 東京, 1964.

4. 和田豊治：臨床脳波, 金原出版, 東京, 1957.

5. Kooi, K.A.: Fundamentals of electroencephalography, Harper and Row, New York, 1971.

6. Scott, D.F. Lichtenheld, F.R., Bickford, R.G., Lambda wave studies on the EEG of animals, Arch. Neurol, 18: 574, 1968.

留問

(爱知総合保七) 川瀨芳克

1．白壁等を見せた時，視覚心像とラム夕波に関する テータは.

2. Visual Attentionが䊒持されているはずの侮に ○ $\alpha$ waveが持続的に出ているケースがあるが, Visual Attention との関連はどの上うに考兊るか.

3.Visual Attentionを持続的に与えた時, はじめ 抑制されていた $\alpha$-wave が再出現するようなととはある か. その祭注意を与えれば再び抑压されるか. 
答弁 1.入波はvisual activity responseである ため，言葉を与えて想像させただけでは入波は出現しな い. 今後てうした実験す行いたいと思います。

2. Y. MVおいては $\alpha$-blockingが認められなかつた
症例である.

3. $\alpha$ 波は開眼により $\alpha$-blocking されるが再び $\alpha$ 波 が出現する場合はある.

\section{術後外斜視の成因についての検討}

\section{順天堂大川村 緑・秋山美よ゙り}

当科において，/才から7オまてにETの手 術を受け術後5年以上, 最高 14 年まで経過を みることのできた154名について，教室の矢沢。 筆者らが5/年6月斜・弱・研でET手術の長期 予後を発表した。この中に術後XTに転じた者 は20\%に及ぶことが分つた。長期経過瀵察者 は，何らかの問題がある為に通院が継続されて いることが多く，その為に高い比率を示寸と考 えられるが,この中術後XT3/名およびその 傾向のみられる/4名について術後XT の成因・ 特にORTが注意しなければならない諸因子, 問 題点を検討してみる.

ETがXTに転ずる過程で，(/) 直接的な要素 として術前の偏位角に対寸る定量, 術式の問題 がある。明らかな過剩の定量は今回の caseに は見られなかつた。術式も両側のM.Rの後転が 外斜視を生じ易いことは47年斜・弱・研で発表 されているので今回は触れない。

(2) 発症年令, 手術時年令别で術後正位を保 つているクループとの比較を行なうと表/の如 く特に有意の差はみられなかつた。但し/才に 手術した者については2/名中9名 $43 \%$ XT に転じていた。また半数は追加手術が行なわれ ているが，早期に行なうものの斜視角が $45 \triangle$ 〜 60வ以上の大きい偏位の為と考えられる。

（3）治瘾の阻害因子としては表2の弱視, 両 眼視機能の不良, ARC (の傾向をもつ者を含む), NPCの不良, 垂直偏位の合併があげられる.勿 論, 術後 XTへの転帰は種々の要素が加わり競
合の状態で起るのであろう。

I ) 屈折, 調節性の因子

屈折異常はアトロピン或いはミドリンPでの レフでの值は, +/D〜3Dまでの遠視は 60 眼 $66 \%,+3 D$ 以上 9 眼 $10 \%,-1 D \sim 3 D$ の近 視眼 7 眼 $7.7 \%,-3 D$ 以上 4 眼 $4 \%$ で著明な 屈折異常はない. 屈折度の比較は同一検者と他 検者差, 同一検者での測定誤差, レフとスキア の差,アトロピンと他散瞳戍の差等で厳密な比 較, 特に経過年数での比較は困難と思之る。

調節性因子は/0才で/5〜/2D，15才/2 〜 10D, 20才で9〜8.5Dと成書に多少の変動 があるが，何れにしても/5才前後まではかな クの調節力を保有していると考えてよいが，6 才前の調節力の検查は信憑性の問題で正確を期 し難い.

II ) 感覚系の因子として両眼視機能

Bifoveal fusion 確立, 完全性, 安定性, peripheral fusion の状態，また对応関係が検討されなけれ ばならない. 恐らく発現年令による差があらう。

\section{表 1 .}

手術時年令

\begin{tabular}{|c|c|c|c|c|c|c|c|c|c|}
\hline \begin{tabular}{|l|} 
発症 \\
年令
\end{tabular} & 手術年令 & 1 & 2 & 3 & 4 & 5 & 6 & 7 & 計 \\
\hline \multirow{2}{*}{ 0才 } & $\begin{array}{c}\mathrm{X} \mathrm{T} \\
\text { (含XT傾向 } 7 \text { 名) }\end{array}$ & $\begin{array}{l}5 \\
(3)\end{array}$ & $\begin{array}{c}3 \\
(3)\end{array}$ & $\begin{array}{c}3 \\
(3)\end{array}$ & $\begin{array}{c}5 \\
(1)\end{array}$ & $\begin{array}{c}3 \\
(1)\end{array}$ & 3 & 1 & $\begin{array}{l}23 \\
\text { (11) }\end{array}$ \\
\hline & O R T H O & & $\begin{array}{c}2 \\
(2) \\
\end{array}$ & \begin{tabular}{|c|}
4 \\
$(2)$ \\
\end{tabular} & \begin{tabular}{|c|}
4 \\
$(2)$ \\
\end{tabular} & $\begin{array}{c}3 \\
(1) \\
\end{array}$ & \begin{tabular}{|c|}
3 \\
$(2)$ \\
\end{tabular} & 1 & $\begin{array}{l}17 \\
(9)\end{array}$ \\
\hline \multirow{2}{*}{$\begin{array}{l}1 才 \\
\text { 以上 }\end{array}$} & $\begin{array}{c}\mathrm{X} \mathrm{T} \\
\text { (含 XT 傾向 7名) }\end{array}$ & & $\begin{array}{c}1 \\
(1)\end{array}$ & $\begin{array}{c}5 \\
(4)\end{array}$ & $\begin{array}{c}4 \\
(1)\end{array}$ & $\begin{array}{c}6 \\
(3)\end{array}$ & $\begin{array}{c}4 \\
(1)\end{array}$ & 2 & $\begin{array}{c}22 \\
(10)\end{array}$ \\
\hline & O R T H O & & & \begin{tabular}{|c|}
5 \\
$(1)$ \\
\end{tabular} & \begin{tabular}{|c|}
4 \\
$(1)$
\end{tabular} & $\begin{array}{c}7 \\
(2) \\
\end{array}$ & \begin{tabular}{|l|}
13 \\
$(4)$
\end{tabular} & 7 & $\begin{array}{l}36 \\
(8)\end{array}$ \\
\hline
\end{tabular}

単位: 名 